\title{
Implementation Strategy of Integrated e-Government Communications Policy by Batang Regent Yoyok Riyo Sudibyo
}

\author{
Rachmi Kurnia Siregar \\ \{rachmi.kurnia@budiluhur.ac.id\} \\ Faculty of Communication Budi Luhur University, Jl. Ciledug Raya, Jakarta, Indonesia
}

\begin{abstract}
The Regency Government of Batang, Central Java led by YoyokRiyoSudibyo at the time of period 2012-2017. He had built bureaucratic modernization, improvement in public services, civil empowerment, and transparency of Regional Budget (APBD) to eradicate corruption, collusion, and nepotism $(\mathrm{KKN})$ through an integrated e-government (e-Gov) system. Corruption involving regional heads in post-reformation Indonesia had gradually increased. The Corruption Eradication Commission's (KPK) statistics recorded that from 2004 up to June 2017, there were 78 regional heads involved in corruption cases of APBD i.e. 18 governors and 60 mayors or regents along with his deputy. This research used qualitative descriptive method, case study, and data triangulation. The purpose of this research is to analyze the following policy strategy e-government integrated communication policy processes and the process of making its policies. The regent was build the system of information integrated data consist of based service technology and information plus Information Management and Documentation Officer (PPID), Budget Festival (FA) and Public Service Quality Improvement Unit (UPKP2), aimed at building bureaucratic reform, prevent corruption and improve public service.
\end{abstract}

Keywords: Communication policy, organizational communication, e-government.

\section{Introduction}

Corruption that involving regional heads in post-reformation Indonesia has gradually increased. The Corruption Eradication Commission's (KPK) statistics recorded 78 regional heads were involved in corruption cases of APBD which were 18 governors and 60 mayors or regent along with his deputy.

Supervision and transparency are not optimal in the Governmentespecially regarding budget accountability has triggered the corruption cases among bureaucrats in local government. The thriving corruption cases in the region cannot be denied as a negative impact of regional autonomy (otda).

Transparency is essential in realizing good public governance in regard to 'clean', democratic, and effective governance. This can be applied as long as the roles of government, private institutions, and citizen are in balance.

The Regent of Batang Yoyok Riyo Sudibyo who began his duty in 2012 tried to build the public trust. This was determined due to the previous regent who caught in APBD (regional budget) corruption cases. 
Various breakthroughs were conducted, such as implementing integrated electronic-based public services (integrated e-government) -for further written as e-Gov based on current development and information communication technology (ICT) development including ePlanning, e-Budgeting, SIMDAKeu (information system of regional management in finance), e-Procurement, and Simpelbang (information system of reports monitoring and evaluation), as well as establishing Documentation and Information Management Officers (PPID) and Public Service for Quality Improvement Unit (UPKP2), and holding Budget Festival (FA).

FA Batang is the responsibility of previous year's utilization of APBD in transparency, dialogically, and directly related to the APBD usage accountability along with development programs to the citizen. Basically, the accountability of APBD is reported to DPRD (Legislative Council). Batang Budget Festival 2016 showcased local budget management followed by dozens of Regional Device Organizations (OPD) and villages by providing booth.

By holding Budget Festival, Yoyok won Bung Hatta Anti-Corruption Award 2015 with the Mayor of Surabaya, Tri Rismaharini. Batang regency, which claimed to be the pioneer of Budget Festival and successfully strengthening the development of e-government system in Indonesia has become the study centre forother government, from districts and cities up to provinces level. Karanganyar regency adopted Budget Festival Batang 2016 yet showcasing the current year budget.

The implementation of e-Gov in the public sector is becoming urgent. Heryana and Dewi (2013) reveal that the implementation of e-Gov has a positive and significant impactin realizing good governance [1].

Besides that, application of e-Government is part of social changes to build public participation and promote reform institutional bureaucracy civil and prevent KKN [2].

This innovation of Yoyok by holding Budget Festival and PPID are to comply with Law No. 14/2008 on Public Information Openness (KIP).

\subsection{Literature Review}

\subsubsection{Communications Policy}

Organization need various strategic plan of a network of functional communication through the activities of communication in accordance vision and mission to achieve the goals. Of these efforts in Andre (2000) explored in communication policy in accordance with agreement in the organization. In other words, communications policy is strategic plan from an organization through a communications network organization functional in achieving its objectives.

According to Unesco communication policy (Aritonang, 2011) is a collection of the norms and normal the principle that made to support the smooth system communication [3]. From definition of above, communication policy made after the formation of a communication system in a state to accomplish a purpose by influence or change the behavior of the people. Communications policy is connected to the development of social, politic, and economy of a country. Abrar (2008) quoted chakravartty and sarikakis (2006) expressing communication policy have a context, the domain and paradigm. Context means the linkage of communications policy with certain aspects such as economic politics, communication politics, environmental politics, and others. This context is important incommunications policy as it determines for the communication policy domain [4].

The domain of communications policy contains the content value in communication policies such as globalization, global economy, and its kind. Domain is a functional context of 
communication policy. For example, related to economic politics, the domain of communication policy is the global economy. Meanwhile, the paradigm is an ideal framework of the intended communication policy, such as the establishment of information society, the strength of civil society, and others. The communications policy has five criteria:1) Have specific purpose, 2) Contained of government officials acts, 3) Demonstrate the actions taken by government, 4) Positive or negative, and 5) Authoritative. Communication policy, sociologically, aims to place the communication process as part of social dynamics that benefit society. The purpose of communication policy supports the smooth communication system within a country [4].

Communications policy is inseparable from public policy. Dye (2008) states, "public policy is an attitude or government decision to do something or otherwise." If the government chooses to carry out the programs there must be a purpose and that policy is concerned with all government actions which is not only statements or wishes of government officials or the government itself. Instead what the government choose not to do is also a state policy. Public policy according to Dunn (2003)is a decision or government action that regulates or influences the actions of individuals in citizen community [5]. From both explanation above, the researcher understands that public policy is an act of government or not to act in influencing or managing individuals and groups of to reach the purpose. In implementing public policy, a number of stages as the work procedure is required to achieve goals and targets.

Dunn (2003) outlines five stages in the interdependent public policy-making process as follows:Setting the agenda; at this stage the policy maker are elected and appointed to classify the issue on the public agenda; Policy formulation; officials formulate a substitute for policy problems and review the need to make executive orders, judicial decisions, and legislative action; Policy adoption; alternative policies were adopted with support from the legislative majority, consensus among director of institutions, or judicial decisions; Policy Implementation: the policies that have been taken are determined after the administrative units mobilize the financial and human resources; Policy evaluation; the audit and accounting units of government assess with the view of determining the executive, legislative, and judicial boards that comply with the laws in policy decisions and goals achievements [5].

\subsubsection{The Theory Bureaucracy Weber}

Communication as basis of life. Every aspect of human life influenced the way of communicating with others. Communication is facility information, education, aims to influence others and process of changing the conduct of others. Lasswell in Mulyana (2008) mention five of an element in processes of communication that is sources (a communicator), message (can be meaning the form of or symbols ), a channel or medium, recipients of a message (communicant) and effects [6].

Individuals in a relationship, group, organisations and the community was involved in communication process through a response and create a message to allow in adapting to its environment. Rogers said the organization is collection of individuals are working to achieve a joint purpose [7]. Individuals are interacting through communication marking the establishment of the organization. Every individual requires the ability to communicate in relationships, society, group or organization to convey a message with a particular purpose. This means that the communication within an organization is an absolute thing in realizing the objectives of the Organization, in addition to various other aspects.

The organization's communications as a effort to sending and receiving messages in either a formal group or organization informal group organization. Organizational communication at 
the District Government of the Batang Regency can be analyzed through a communication policy strategy e-gov is integrated in APBD governance in an era of Regent Yoyok Riyo Sudibyo. This is in accordance of essence of the theory bureaucracyof Weber who insists on the role of the individual as initiator in an organization [8]. According to Weber, organization is a system interpersonal activities designed to set individual duty. The organization as bureaucracy. There are three the basic principles in bureaucracy i.e authority, specialization and regulations. If those it was not applied, impossible bureaucracy can be achieved. From the explanation above, researcher confine in looked at how Regent Yoyok acting rationally to achieve its goal by applying communication policy e-gov integrated as the subject this research. It is connected with the Theory of Bureaucracy Weber which includes factors authority, specialization and rules in a bureaucracy.

\subsubsection{E-Government}

Government uses information technology to make a change for the contact with the community, the business world and all aspects of concerned.This is in accordance with the definition issued by World Bank about electronic government [9]. Implementation of technology in e government aimed at stepping up the quality of public services. Kumar and Best, (2006) E-Gov. can be applied at the level of executive, legislative, judicial, or public administration. E-Gov. information system service covers government to government, citizen and business. Application e-gov believed to be able to rebuild the relationship between the community and the government [10].

Corruption prevention, collusion and nepotism by creating transparent, effective and efficient in indonesia in the post reformation era through the application of e-government. Government regulations in accordance Inpres No. 3/2003 explained the goal of the application of e government to create a transparent government, effective and efficient. In particular, eGov. is a public information system applied by government in transforming relationships with the public, private, and various related parties that supported with ICT devices as the current development in globalization era that aims to improve the quality of effective, efficient, transparent, and democratic public services in realizing the accountable, participatory, and KKN-free governance [11]. Center for Democracy and Technology and Infodev (Hasibuan, 2007) outlines mechanism e-government in three stages: 1) Publish: The government uses information technology to opening access information to the public; 2) Interact: build community participation in government [12].

For example, create an interactive site with the citizen, as well as bridge interfaces connection with other institution; 3) Transact: the government provides various online public services. For example, create public transactions service site, as well as interoperability of applications and data with other institutions It requires assurance and commitment from stakeholders including the regional head to work those three stages successfully as expected and of course with the concern of current condition in infrastructure, service activities, budget, and human resource. The problems of this research are: a) The increase of national budget $(\mathrm{APBN})$ and regional budget (APBD) have not been supported by the transparent budget management that is easily triggered corruption, collusion, and nepotisms, particularly in local government; b) Some citizens are still at difficulty to access public information about budget governance including local financial management and development. Based on the problem identification, the problem limitations in this study are: a) Communications policy strategy of Batang Regent Yoyok Riyo Sudibyo to open public information regarding financial management and development; b) Communication policy and policy-making process of 
integrated e-government communication. Based on the problem identification and limitation, the problem formulation in this research are: a) How is the strategy of integrated egovernment communication policy in the reign of Batang Regent Yoyok Riyo Sudibyo ? b) How is the process of the communication policy and policy-making of integrated egovernment communication?

\section{Methods}

This research is done at Batang Regency in 2017, Central Java, with a qualitative approach descriptive and case studies. A qualitative approach according to Moleong (2013) research is aimed at a grasp phenomena by the subject of study in the context of natural using scientific method. The understanding will be reached on a general qualitative research against social reality [13].

Researcher is interested in researching the phenomenon of transparency in the governance of APBD by the Regent Yoyok through the application of data integration between information systems.

While the method of research with case studies according to Kriyantono (2006)aims to comprehensively explain the various aspects of theobject of research is the goal of systematically research case studies [14].

In this research, the technique of data collection was carried out from interviews with Yoyok Riyo Sudibyo and his staff, the local house of representatives, NGO's anti corruption, and the community. Researcher also conducting observations and documentation.

Data analyzed in interpretive and triangulation of data. Analysis interpretive used to formulate communication policy e-gov integrated.

\section{Results and Discussion}

This research was conducted with qualitative approach, its implementation was focused on organizational communication regarding the strategy of e-Gov. communication policy through analysis of integrated e-Gov. communication policy and its policy making.

\subsection{The Strategy of Integrated E-Gov Communication Policy}

The field of government administration e-gov integrated at the local government a stem at the era of Yoyok includes: e-Planning; electronics-based Information Systems of Regional Development Planning,e-Budgeting; a web-based system to facilitate the agenda of APBD,SIMDA (Information System of Regional Management) Finance,e-Procurement; a web-based system for goods procurement and services, Simpelbang; an integrated information system of General Plan of Procurement (RUP),SIMDA Goods,e-SAKIP; an accountability system of government performance. This system is an integrated planning system, budgeting system, and performance report system that in line with the implementation of financial accountability system and Simpeg which is a personnel information management system, as well as PPID, Budget Festival, and UPKP2.

The figure 1 is the government implementation on integrated e-Gov administration in the reign of Batang Regent Yoyok Riyo Sudibyo. 


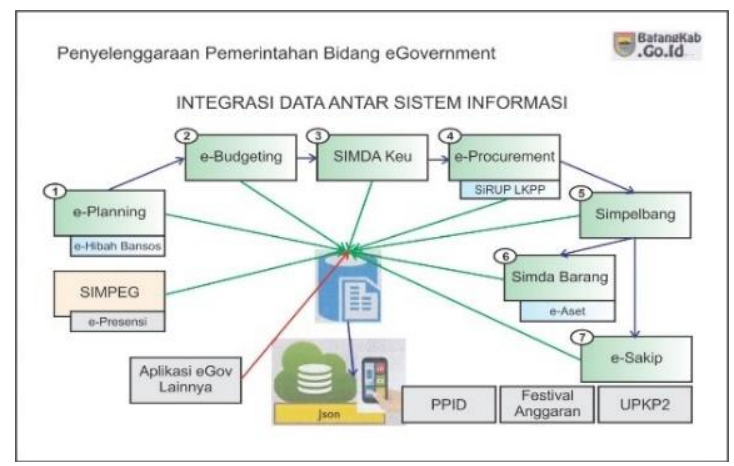

Fig. 1. Government Implementation of e-Gov in the Reign of Yoyok Riyo Sudibyo.

\subsection{Information Management and Documentation Officer (PPID)}

The need of information for individual becomes important in personal and social development which is also the main thing in national defensenational defense. The right to obtain of information is a human right and the need for public information is one of the important features on democratic country. The task of PPID is to provide the access of public information for information applicant. According the mandate in article 13 Law No. 14/ 2008, Batang regency formed PPID through BupatiBatang Decision number 485.2/240/2013 on the establishment of PPID. The government shall fulfill the public right of public information that assured on the KIP Law. This Act regulates: 1)every individual has the right to obtain information; (2) the obligations of the government to provide and serve information requests promptly, timely, in low cost, and in simple ways; (3) exceptions are strict and limited; (4) government responsibility to manage the system of documentation and information. The figure 2 is PPID of the rod was quoted as saying in the PPID of Batang.

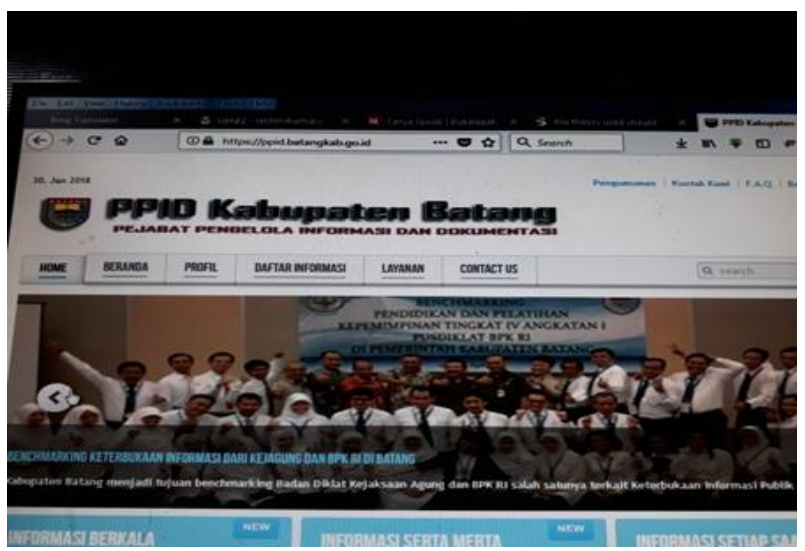

Fig. 2. PPID Batang. 


\subsection{Budget Festival (FA)}

Festival, according to Stoeltje (1992) in Indriasari(2009) is a periodic social event that is coordinated and involved directly or indirectly by a community/organization in order to create a mutual exchange of views between one to the other [15]. The festival according to Kaeppler (1987) is an important medium of communication to build and empower regional characteristics, and as recognition of a cultural identity. Developing areas usually hold the festival for those purposes. Festival as an event aims as a medium of communication for a city in displaying particular characteristics as the uniqueness of the region. The implementation of the festival is expected to encourage the development in all fields and increasing the investment and reputation of the region. Every activity including the implementation of government activities requires an allocated budget from APBN or APBD to finance the development.

Budget Festival is communication media in order to realize the transparency of local budget utilization and recent working plan for a certain period that involved money, which is presented to the public as a routine activity of Batang regency. Transparency of APBD management through Budget Festivals as an implementation of governance according to Law No. 28/1999 concerning the governments enforcement transparent, accountable, effective and effisien. The figure 3 is pictures of the festival budget 2016 .

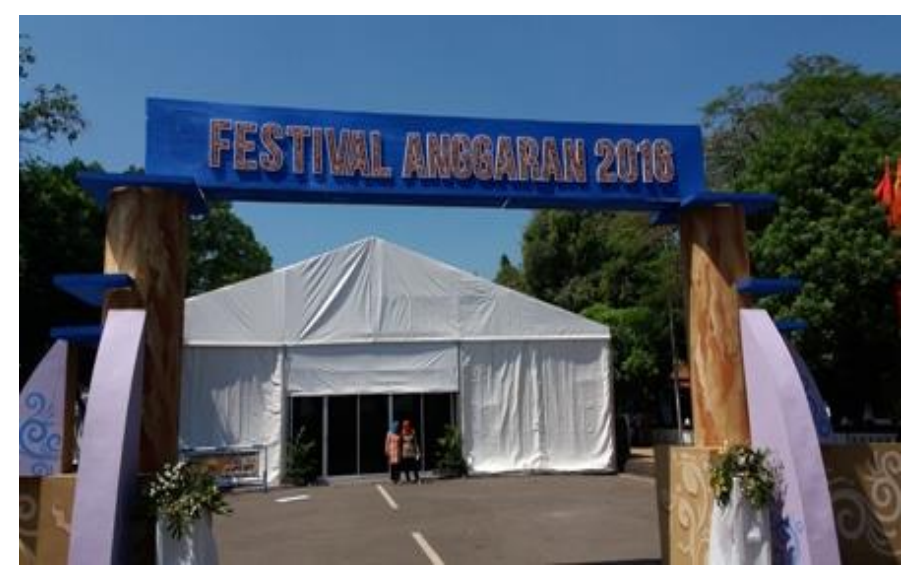

Fig. 3. Festival Budget 2016.

\subsection{Public Service Quality Improvement Unit}

In strengthening the integrated e-Gov., Yoyok established UPKP2 based on Regent's Regulation No. 90/2012 on Improving the Quality of Public Service in Batang regency. Public service an important aspect in applying effective governance, efficient, accountable and transparent and as a bridge to community welfare. In addition the levels of trust public is strongly influenced by the service provided regional governments or centerr.Government regulation regarding public service issued to create transparent government, accountable, effective and effisien. The regulations include Law No. 14/2008 on KIP, Law No. 25/2009 on Public Service, Government Regulation No. 65/2005 on Guidelines for Preparation and Implementation of Public Services, Presidential Regulation No. 55/2012 concerning National 
Strategy for Long Term Prevention and Eradication of Corruption in 2012-2025 and for medium term in 2012-2014. In general, this ad hoc institution aims to build public trustof the government apparatus in Batang regency which marked by the process of service improvement for Prosperous Batang citizen. According to Regent Regulation No. 90/2012, UPKP2 as the authorities who receivethe reports and/or public complaints, conduct surveys on citizen reports/complaints, analyze the causes of complaints, and develop action plans for real service improvements, as well as monitor the work performance of service implementers and evaluate the service outcomes and also recommend the regent regarding the improvement of the public service quality.

\subsection{Analysis of Communications Policy}

Communication policy is a strategic plan of an organization to reachcertain goals. Communications policy is influenced by the social, political, and economic development of a country. Chakravartty and Sarikakis (2006) in Abrar (2008) point out that communication policies have context, domains, and paradigms [4]. As a whole content of the context, domain, and paradigm, integrated e-Gov. communications policy as explained by Batang Regent period 2012-2017 Yoyok is as follows: "The government continues to realize good governance, one of them is through the accurate and adequate public information transparency about the government to the public in order to prevent KKN. This is realized by the government by issuing various regulations related to public services that one of the goals is for the community prosperity.

"Communication activities are also included as political activities. Communication according to Barnlund (Nimmo, 2005) is a transactions process of an individual in creating and giving meaning to realize the individual goals [16]. Integrated e-Gov. communication policy was applied through meetings and socialization that comes from the idea of Batang Regent Yoyok. Initially, the communication that used to work tend to be in one way, but then developed into transactional communication after Regent Yoyokdevelop the network with the competent authorities.Among them were the Corruption Eradication Commission (KPK), Transparency International Indonesia (TII), Indonesian Corruption Watch (ICW), Ombudsman Republic of Indonesia, Development Finance Comptroller(BPKP), Indonesian Forum for Budget Transparency (FITRA), Villages, Disadvantaged Regions and Transmigration Minister RI, Mayor of Surabaya Tri Rismaharini, and others within which an exchange of ideas, knowledge, and information commonly occurred. There are two ways in analyzing the communication policy: positive public policy and normative analysis. Cohcran and Malone (1992) in Abrar (2008)describe positive public policy as to emphasize the work of policy process, while normative analysis (Cohcran, 1992) is more focused on the assessment that should be included in the policy [4].

Lasswell in Mulyana (2008) states there are five elements in the communication process i.e. source (sender of message/communicator), message (as meaning, form, or symbol), channel or media used by the sender, the message recipient (communicant)and the effect [6]. Communication is a tool of power that leads to political interests. Sources or political communicators seek influences through communication [16]. Related to Laswell's theory on integrated e-Gov. communications policy process, Batang Regent Yoyok who was supported by a number of political parties played the role as communicator to convey ideas in order to open broad access in the budget transparency and integrated e-Gov.-based public services. Communicants including the staff of Batang regency, society, parliament, government institutions, and anti-corruption NGOs. The expected effects are to build public trust, close the 
opportunities of corruption, and learning center for other areas. The analysis of communication policy based on normative policy is related to prescribed norms and rules in society according to the Constitution of 1945 and Pancasila. The process of integrated e-Gov. communication policy is made as in the table 1.

Table 1. Integrated E-Gov Communication Policy Process.

\begin{tabular}{|c|c|c|c|c|}
\hline Communicator & Message & Channel & Communicant & Effect \\
\hline Regent of Batang & The & Integrated E-Gov. & PNS & The \\
\hline in period 2012- & 1mplementation & & Batang & Improveme \\
\hline $\begin{array}{l}\text { Sudibyo } \\
\text { Sul, Y Oуоккіуо }\end{array}$ & $\begin{array}{l}\text { of effective } \\
\text { governance, }\end{array}$ & Meeting. & Regency & $\begin{array}{l}\text { nt of pubilc } \\
\text { services }\end{array}$ \\
\hline \multirow{6}{*}{$\begin{array}{l}\text { Location: } \\
\text { BatangRegency. }\end{array}$} & $\begin{array}{l}\text { efficient, } \\
\text { accountable and }\end{array}$ & Socialization. & DPRD. & quality. \\
\hline & transparent. & Discussion. & Institutional & The citizen \\
\hline & \multirow{4}{*}{$\begin{array}{l}\text { Prevent and } \\
\text { eradicate KKN. }\end{array}$} & \multirow{2}{*}{ Press conference. } & government. & $\begin{array}{l}\text { Is critical or } \\
\text { the }\end{array}$ \\
\hline & & & NGOs. & government. \\
\hline & & $\begin{array}{l}\text { Advertising } \quad \text { in } \\
\text { mass media. }\end{array}$ & Citizen. & Policy \\
\hline & & & Professional. & $\begin{array}{l}\text { the } \\
\text { stakeholders }\end{array}$ \\
\hline
\end{tabular}

\subsection{Analysis of Communication Policy Decision Making}

The integrated e-Gov. policy initiated by Batang Regent Yoyok is a political policy aimed at building a communicative tradition between the district government and the citizens in administering the government proportionally and professionally. This political activity is implemented in the policy-making process.

(Dunn, 2003) outlines five stages of the interdependent of public policy making process that arranged in the time order: agenda formulation, policy formulation, policy adoption, policy implementation, and evaluation as follows [5]:

1. Arrangement of agenda. (Abrar, 2008)there are three activities that must be done 1) build perception among stakeholders about the problem to be solved, 2) create problem limitation, and 3) mobilize supports in order to put in the issues in the government agenda [4]. Of the integrated e-Gov, Yoyok explains as follows: "Other than implementing an electronic-based public service system, I also established UPKP2, PPID, and Budget Festival as part of direct transparency and accountability to the people regarding the usage of APBD as my commitment for the society. Of which to eradicate $K K N$ and also to build public participation."

2. Stages of communication policy formulation is closely related to the prevailing communication system within a country [4]. Yoyok's efforts to implement integrated e-Gov. refers to a number of regulations. In particular, electronic-based public services is based on Presidential Instruction (Inpres) No. 3/2003 on national policies and strategies for e-Gov. development. PPID is as mandated by Article 13 of Law No. 14/ 2008 on KIP and established through Batang Regent Decision No. 485.2/240/2013 on the establishment of PPID. UPKP2 is 
based on Law No. 25/2009 on Public Services which is firmed through Regional Law No. 90/2012. Of Budget Festival, there is no specific regulation yet referred to RPJMD of Batang regency allocated in DPKAD budget.

3. Stages of policies adoption; the Regent Yoyok claimed that integrated e-Gov. implementation is supported by legislatives, aside from society, bureaucrats, professionals, and anti-corruption NGOs such as FITRA, ICW, and TII.

4. Stages of policy Implementation; integrated e-Gov. policy is carried out in Batang district government during Yoyok era which according to vision and mission to create electronicbased government system supported by PPID, FA, and UPKP2.

5. Policy evaluation; Evaluation is an activity of analyzing and presenting information about the evaluation object, ensuring the appropriateness of strategic action to the initial design or strategic formulation set. Of Budget Festival 2016 which is part of e-Gov. integration did not run as planned due to lack of team cooperation.

\section{Conclusion}

Based on the research conducted, there are some conclusions as follows:

1. Integrated e-government communication policy is a political policy initiated by Yoyok as a communicator in conveying messages to his staff as part of bureaucratic reform and improvement of IT-based public services, and also supported by PPID, Budget Festival, and UPKP2 as part of data integration between information systems.

2. Strategies policies communication e-government integrated by Regent of Yoyok moderated in data integration between information system, aimed at building bureaucratic reform, prevent corruption and improve public service.

3. The policy making process of integrated e-government communications according to Dunn (2003) begins with the agenda preparation that carries the theme of bureaucracy reformation, transparency and development of APBD governance, and also the improvement of public and participative services.

Acknowledgments. We would like to thank to Yayasan Budi LuhurCakti, University of Budi Luhur (UBL), Faculty of Communication (UBL), Ministry of Research, Technology, and Education Republic of Indonesia, Director of Research and Community Service UBL, Regent of Batang, Central Java, and various parties who contributed in this research.

\section{References}

[1]T. Heryana and S. K. Dewi, "Pengaruh Penerapan E-Government Terhadap Pelaksanaan Tata Kelola Pemerintah di Pemkab Cianjur," Jurnal Riset Akuntansi dan Keuangan, 2013. .

[2]J. C. Bertot, P. T. Jaeger, and J. M. Grimes, "Using ICTs to create a culture of transparency: Egovernment and social media as openness and anti-corruption tools for societies," Gov. Inf. Q., vol. 27, no. 3, pp. 264-271, 2010.

[3]A. I. Aritonang, "Kebijakan Komunikasi di Indonesia: Gambaran Implementasi UU No. 14 tahun 2008 tentang Keterbukaan Informasi Publik,” J. Komun., vol. 1, no. 3, pp. 261-286, 2011.

[4]A. N. Abrar, Kebijakan Komunikasi: Konsep, Hakekat dan Praktek. Yogyakarta: Gava Media, 2008.

[5]W. N. Dunn, Pengantar Analisis Kebijakan Publik. Yogyakarta: Gajah Mada University Press, 2003.

[6]D. Mulyana, Ilmu Komunikasi Suatu Pengantar. Bandung: Remaja Rosdakarya, 2008.

[7]H. Afdjani, Ilmu Komunikasi, Proses dan Strategi, II. Jakarta: Universitas Budi Luhur dan Indigo Media, 2014. 
[8]S. W.Littlejohn, Teori Komunikasi. Jakarta: Salemba Humanika, 2011.

[9]W. Bank, "The definition of e government," World Bank, 2015. .

[10]V. Kumar, B. Mukerji, I. Butt, and A. Persaud, "Factors for Successful e-Government Adoption : a Conceptual Framework," Electron. J. e- Gov., vol. 5, no. 1, pp. 63-76, 2007.

[11]R. K. Siregar and W. M. Arlena, "Komunikasi Organisasi Pengelolaan APBD (Kebijakan Tata Kelola APBD Berbasis E-Government Plus Pada Pemerintah Kabupaten Batang, Jawa Tengah)," 2017, vol. 01, no. 01, pp. 183-193.

[12]Z. A. Hasibuan, "Langkah-Langkah Strategis dan Taktis Pengembangan E-Government Untuk Pemerintah Daerah,” Sist. Inf. MTI Univ. Indones., vol. 3, no. 1, pp. 66-70, 2007.

[13]L. J. Moleong, Metodologi Penelitian Kualitatif, II. Bandung: Remaja Rosdakarya, 2013.

[14]Kriyantono, Riset Komunikasi. Jakarta: Grafindo Persada, 2006.

[15]S. Indriasari, "Pengelolaan Festival Budaya di Indonesia. Studi Kasus Pengelolaan Festival Tradisi Lisan Maritim Wakatobi," University of Indonesia, 2009.

[16]D. Nimmo, Komunikasi Politik: Komunikator, Pesan dan Media. Bandung: PT Remaja Rosdakarya, 2005. 